\title{
Impact of dietary glutathione on hematological indices in rats poisoned with hexavalent chromium
}

\author{
Ajay K umar ${ }^{1 *}$ and Alok K umar ${ }^{2}$ \\ ${ }^{1}$ Department of Zoology, Chinmaya Degree College, Haridwar-249403 (UK), INDIA \\ ${ }^{2}$ Department of Chemistry, Chinmaya Degree College, Haridwar-249403 (UK), INDIA \\ *Corresponding author. E-mail: ajaykumar232099@gmail.com \\ Received:April 20, 2013; Revised received: M ay 18, 2013; Accepted: J une 05, 2013
}

Abstract: The effects of dietary glutathione against chromium induced hematological indices were studied in rats, Rattus rattus albino. Supplementation of glutahione to the diet of chromium fed rats, elevated significantly percent hemoglobin $(40.4 \%)$, number of red blood corpuscles $(48.7 \%)$, plasma corpuscular volume $(43.4 \%)$ and mean corpuscular volume (37.1\%) which were inhibited in chromium poisoned rats. However, no marked elevation was noticed in number of white blood corpuscles and total proteins. Intake of glutahione checked the accumulation of glucose, cholesterol, tryglcerides, phospholipids and bilirubin in chromium treated rats. Chromium intoxication significantly increased the activities of transaminases $(p<0.001)$ and dehydrogenases $(p<0.01 / p<0.001)$ which declined by supplementation of gltathione which also restored the chromium inhibited activity of alkaline and acid phosphatase. Specific reasons for these pharmacoticological aspects of glutathione have also been discussed.

Keywords: Glutathione, Chromium, Blood, Enzymes, Rat

\section{INTRODUCTION}

Mild to serious and even fatal consequences have been reported when human beings and other mammals are exposed to excessive amounts of chromium (Enterline, 1974; Levy and Venitt, 1986; Kumar and Barthwal, 1991). Although chromium, in traces, is known to be essential for the growth and well being of men and animals (Mertz, 1974). In mammals, hexavalent chromium cause more damage than did trivalent chromium after an intraperitoneal administration of potassium dichromate or chromium nitrate (Tandon, 1982). Now it is an agreed fact that under nutritional deficiency, the heavy metal toxicity is potentiated (Kumar et al., 1987; Kumar and Kumar, 2003). Under vitamin C deficient condition, toxic effects of Co, Mn and Mo are more prominent (Chatterji et al., 1977). Protection offered by dietary methionine on blood constituents in $\mathrm{Cr}$ poisoned rats were also reported (Kumar and Kumar, 2003). Vitamins induced inhibition of heavy metal accumulation in rats reported by Kumar and Kumar (2006). Role of glutathione in modifying arsenic induced hepatic dysenzymia in rats already been reported by present authors (2011). Recently Kumar (2012) studied the impact of glutathione on hematological constituents in arsenic poisoned rats. But, the information on protective effects of glutahione specially against chromium toxicity is meagre. Since hematological studies constitute one of the earlier and important indices of chemical toxicity as well as blood plays an integrated and inevitable part in the immune system (Kori-Siakpere and Ubogu, 2008) should be influenced by supplementation of dietary glutathione. Therefore, it has been proposed to investigate the effectiveness of gluthathione against chromium induced gross changes in blood constituents of albino rats, Rattus rattus albino.

\section{MATERIALS AND METHODS}

Thirty laboratory bred, male albino rats (Rattus rattus ablino), 90 days old and weighing $100 \pm 10$ gm were selected for the present study. Each rats was housed separately in a plastic cage bedded with rice husk, fed on standard laboratory diet (Hindustan Lever Ltd., Bombay) and tap water ad libitum. The animals were divided at random into three groups each containing 10 rats. Rats of group I served as control, received the laboratory diet alone and tap water. Rats of group II and III in addition to receiving pellet diet, were fed by gavage with hexavalent chromium in the form of potassium chromate at the dosage of $0.5 \mathrm{gm} / \mathrm{kg}$ body weight on each day for 30 days. Whereas, the animals of group III were also supplemented with glutathione at the dosage of $0.25 \mathrm{gm} /$ $\mathrm{kg}$ body weight in addition to potassium chromate on each day for the same duration. After 30 days of treatments, all the rats were starved overnight and blood was drawn from the caudal vein with a heparinized syringe. The hemoglobin $(\mathrm{Hb})$ percent, total red blood corpuscles (RBC), white blood corpuscles (WBC) and plasma corpuscular volume (PCV) were determined 
according to the method of Dacie and Lewis (1977). From these data 'absolute value' for mean corpuscular volume (MCV) and mean corpuscular hemoglobin concentration (MCHC) were calculated.

Total plasma proteins were estimated using bovine serum albumin as standard (Lowry et al., 1951). Serum was analysed for glucose (Marks, 1959), cholesterol (Oser, 1976), triglycerides (Jover, 1963), phospholipids (Frings and Frendley, 1972), bilirubin (Oser, 1976) and urea (Marsh et al., 1951). The activities of alkaline and acid phosphatase, glutamic oxaloacetic transaminase (GOT), glutamic pyruvic transaminase (GPT), lactate and glutamate dehydrogenases were estimated as described by Bergmeyer (1974). Student's 't' - test (Fisher, 1950) was employed to calculate the statistical significance between control and experimental values. The gross changes in hematological indices of chromium poisoned rats (Group-II) were compared with controls (Group-I), whereas the data on hematological parameters of chromium + glutathione (Group-III) were compared with chromium poisoned rats (Group-II).

\section{RESULTS AND DISCUSSION}

During the experiments the rats were active and there was no overt signs of toxicosis, although reduced weight gain was observed in chromium fed rats, whereas rats of group-III which are supplemented with glutathione exhibit increased weight gain when compared to chromium poisoned rats. Results presented in Table 1, exhibited chromium induced gross changes in hematological parameters and their modification by supplementary glutathione. Rats poisoned with hexavalent chromium became anemic as evidenced by a significant inhibition in percent $\mathrm{Hb}$ and total $\mathrm{RBC}$. Since there was a decrease in MCV and PCV, hemorrhage was possibly inflicted by this metal which subsequently induced anemia; this is supported by observation of Tandon et al.(1978); Kumar and Barthwal (1991). Supplementation of glutahinone to the diet of chromium fed rats induced a significant elevation in above hematological constituents. Recently Kumar (2012) also reported the same observation regarding the protective influence of glutathione in modifying hematological indices in arsenic poisoned rats. Addition of high protein in the diet of rats fed on high level of copper and chromium also retained less copper and chromium respectively in hepatic tissue (Kumar et al., 2003; 2009 and 2011).

The level of serum triglycerides, phosholipids, cholesterol and glucose were elevated significantly in rats fed on chromium. The absorption of metal in excess disturbs the metabolism of lipids and cholesterol. Heavy metals are known to cause hyperlipaemia in experimental animals (Caplan and Block, 1963; Rana and Kumar, 1980; Kumar and Rana, 1982). These results suggest a blockade in the process of oxidative phosphorylation. Since inhibition of oxidative phosphorylation is known to raise the accumulation of lipids (Hartmann, 1960). A significant decrease in total cholesterol, triglycerides and phospholipids after supplementation of glutathione support the observation of Sharma et al., (2007). The increase in blood glucose level in chromium poisoned rats support the findings of Kumar and Bharthwal (1991) who observed significant variations in blood sugar level of rats fed on hexavalent chromium. The condition of hyperglycaemia indicated disrupted carbohydrate metabolism which might have been due to enhanced breakdown of liver glycogen which declined after supplementation of glutathione as exhibited by a significant decrease in blood glucose level. Rats exposed to chromium (vi) induced a significant rise in serum urea levels is an indication of renal damage. Kumar and Rana (1984) observed considerable Kidney damage in chromium poisoned rats resulting in significant functional impairement, necrosis and loss of enzyme activity from the renal tubules. Increase in bilirubin as reported in present study is known to interfere with mitochondrial respiration and cause uncoupling of oxidative phosphorylation (Mustafa et al., 1969)

The enzyme activity of alkaline and acid phosphatase was inhibited in rats fed on chromium reflects damge to plasma membrane and lysosomes. However, the activities of these enzymes were also inhibited in hepato-renal tissue of rats poisoned with chromium (Kumar and Rana, 1984; Kumar et al., 1985). A significant increase in the activity of GOT and GPT is indicative of liver dysfunction (Rajanna et al., 1981). Plasma activity of GDH, an index of mitochondrial injury and LDH which is a marker of tissue damage (Schmidt and Schmidt, 1974) elevated significantly in chromium intoxicated rats, but addition of glutathione to the diet of chromium fed rats inhibited enzyme activity significanlty. Chromium induced increased activity of serum eznymes was probably due to leakage of these enzymes from injured tissue into blood (Rees and Sinha, 1960). Supplement of glutathione to $\mathrm{Cr}$ fed rats provides certain amount of protection and have the capacity to correct liver dysfunction and confirm the protection by modifying the enzyme activities. To understand how glutathione which is essential for normal metabolic function, may affect chromium toxicity. Jensen and Maurice (1979) hypothesized that glutathione may (i) Diminish the absorption of chromium, (ii) Form a complex with chromium in vivo, (iii) Enhance the synthesis of chromium binding proteins and (iv) Increase the biliary excretion of chromium.

The present study concluded that glutathione which is a small protein composed of three amino acids- cysteine, glutamic acid and glycine involved in detoxification and 
Table 1. Influence of dietary glutathione on hematological indices in chromium poisoned rats.

\begin{tabular}{|c|c|c|c|c|c|}
\hline \multirow[t]{2}{*}{ B lood constituent } & Control & Chromium & Alteration & Chromium + & Alteration \\
\hline & (G roup-I) & (G roup-II) & $(\%)$ & $\begin{array}{l}\text { G lutathione } \\
\text { (Group-III) }\end{array}$ & $(\%)$ \\
\hline Hemoglobin $(g / d l)$ & $13.42 \pm 0.8$ & $7.80 \pm 1.6 * * *$ & $41.9(-)$ & $10.95 \pm 1.9 * *$ & $40.4(+)$ \\
\hline R B C $\left(10^{6} / \mathrm{m} \mathrm{m}^{3}\right)$ & $6.82 \pm 0.5$ & $4.10 \pm 1.0 * *$ & $39.8(-)$ & $6.10 \pm 0.7 * *$ & $48.7(t)$ \\
\hline W B C $\left(10^{3} / \mathrm{m} \mathrm{m}^{3}\right)$ & $8.20 \pm 0.9$ & $7.40 \pm 1.4^{\mathrm{NS}}$ & $9.7(-)$ & $7.94 \pm 1.2^{\mathrm{NS}}$ & $0.5(+)$ \\
\hline $\operatorname{PCV}(\%)$ & $39.30 \pm 2.0$ & $22.80 \pm 2.0 * * *$ & $42.0(-)$ & $32.70 \pm 2.3 * * *$ & $43.4(+)$ \\
\hline $\mathrm{M} \mathrm{C} \mathrm{V}\left(\mu \mathrm{m}^{3}\right)$ & $57.62 \pm 2.8$ & $35.60 \pm 3.0 * * *$ & $38.2(-)$ & $48.80 \pm 2.8 * *$ & $37.1(t)$ \\
\hline M C H $\left(10^{-12} \mathrm{~g}\right)$ & $19.67 \pm 1.2$ & $19.02 \pm 1.8^{\mathrm{NS}}$ & $3.3(-)$ & $18.90 \pm 2.0^{\mathrm{NS}}$ & $0.6(-)$ \\
\hline M CHC $(\%)$ & $34.14 \pm 2.0$ & $34.21 \pm 2.2^{\mathrm{Ns}}$ & $0.2(+)$ & $33.80 \pm 1.9^{\mathrm{NS}}$ & $1.2(+)$ \\
\hline Totalprotein $(\mathrm{g} / \mathrm{d} \mathrm{l})$ & $7.68 \pm 0.9$ & $6.80 \pm 1.2^{\mathrm{Ns}}$ & $11.4(-)$ & $6.86 \pm 1.1^{\mathrm{NS}}$ & $0.8(+)$ \\
\hline Glucose $(\mathrm{mg} / \mathrm{dl})$ & $82.00 \pm 3.3$ & $94.10 \pm 6.2 *$ & $14.7(+)$ & $88.00 \pm 5.8^{\mathrm{NS}}$ & $6.4(-)$ \\
\hline Cholesterol (m g/dl) & $93.00 \pm 7.0$ & $115.2 \pm 7.0 * * *$ & $23.8(+)$ & $102.6 \pm 6.0 * *$ & $11.0(-)$ \\
\hline Triglycerides (m g/d l) & $82.20 \pm 5.8$ & $98.00 \pm 6.0 *$ & $19.2(+)$ & $86.00 \pm 5.2 *$ & $12.2(-)$ \\
\hline Phospholipids (mg/dl) & $130.0 \pm 4.2$ & $154.2 \pm 6.8 * *$ & $18.6(+)$ & $135.1 \pm 5.8 * *$ & $12.4(-)$ \\
\hline Bilirubin $(\mathrm{m} g / \mathrm{dl})$ & $0.32 \pm 0.1$ & $0.50 \pm 0.8 *$ & $56.2(+)$ & $0.48 \pm 0.8^{\mathrm{NS}}$ & $4.0(-)$ \\
\hline Urea (m g N/dl) & $16.25 \pm 2.1$ & $32.50 \pm 3.0 * *$ & $100.0(+)$ & $20.30 \pm 3.8 * *$ & $37.5(-)$ \\
\hline G 0 T (IU) & $40.00 \pm 3.2$ & $62.00 \pm 4.8 * * *$ & $55.0(+)$ & $50.00 \pm 5.0 * *$ & $19.3(-)$ \\
\hline G PT (IU ) & $12.00 \pm 2.0$ & $25.20 \pm 4.3 * * *$ & $110.0(+)$ & $17.60 \pm 5.0 * *$ & $30.1(-)$ \\
\hline $\begin{array}{l}\text { A lkaline phosphatase } \\
\left(\mu \mathrm{m} 0 \operatorname{lp}^{\mathrm{NP}} / \text { liter }\right)\end{array}$ & $47.00 \pm 4.2$ & $32.20 \pm 5.0 * * *$ & $31.9(-)$ & $35.00 \pm 6.0^{\mathrm{NS}}$ & $8.5(+)$ \\
\hline $\begin{array}{l}\text { A cid phosphatase } \\
\left(\mu \mathrm{molp}{ }^{N P} / \text { liter }\right)\end{array}$ & $28.50 \pm 3.8$ & $16.20 \pm 3.4 * *$ & $43.1(-)$ & $25.00 \pm 4.1^{* *}$ & $54.3(+)$ \\
\hline $\begin{array}{l}\text { Lactate dehydrogenase } \\
\text { (IU/liter) }\end{array}$ & $190.0 \pm 12.0$ & $240.0 \pm 13.0 * * *$ & $26.3(+)$ & $205.0 \pm 14.2 * *$ & $14.6(-)$ \\
\hline $\begin{array}{l}\text { G lutam ate dehydrogenase } \\
\text { (IU /liter) }\end{array}$ & $2.60 \pm 1.0$ & $6.40 \pm 1.4 * *$ & $146.1(+)$ & $5.50 \pm 2.0^{\mathrm{NS}}$ & $14.1(-)$ \\
\hline
\end{tabular}

All values are mean \pm SEM of five observations; (+), \% stimulation; (-), \% inhibition; NS, not significant, $p^{\mathrm{NP}}, p$-nitrophenol; IU, International units; Asterisks indicate that values are significant at $* \mathrm{p}<0.05 ; * * \mathrm{P}<0.01 ; * * * \mathrm{p}<0.001$ (Fisher's 't'-test), when values of Group-II compared with Group-I; Group-III compared with Group-II.

antioxidant mechanisms, is protective and effective in modifying gross changes in hematological indices induced by hexavalent chromium in rats. But one should be careful in selecting the dose, as species difference in glutathione tolerance may occur.

\section{ACKNOWLEDGEMENT}

Financial assistance to one of the author (Ajay Kumar) by the University Grants Commission, New Delhi, is gratefully acknowledged.

\section{REFERENCES}

Caplan, R.M. and Block, W.D. (1963). Experimental production of hyperlipaemia in rabbit by cobalt chloride. J . Invest. D ermatol., 40:199-204.

Chatterji, G.G., Chakraborty,D., Bhattacharya, A. and Mazumdar, K. (1977). Vitamin C deficiency after heavy metal toxicity. Int.J . Vit.N utr. Res., 47:81-89.

Enterline,P.E. (1974). Respiratory cancer among chromate workers. J. Occup. M ed., 16:523-526.

Fisher, R.A. (1950). Statistical methods for research workers.
11 th Edn., Oliver and Boyd, Edinburgh.

Frings, C.S. and Frendley, T.W. (1972). Improved determination of serum lipids by the suophosphovanillin reaction. Clin.Chem., 18:673-674.

Hartmann, F. (1960). Oxidative phosphorylation and lipid accumulation in animals. G astroenterol., 116:156-158.

Jensen, I.S. and Maurice, D.V. (1979). Influence of sulfur amino acids on copper toxicity in chicks. J. Nutr., 92:173-178.

Jover, A. (1963). A technique for determination of serum glycerides. J. Lip. Res., 4:228-230.

Kori-Siakpere, O. and Ubogu, E.O. (2008). Sublethal hematological effects of Zinc on the fresh water fish, Heteroclarias sp.African J. Biotechnol., 7:2068-2073.

Kumar, A. (2012). Role of glutathione in modifying arsenic induced hematological indices in rats. J. Sust. Env. Res., 1: 53-56.

Kumar, A and Barthwal, R. (1991). Heaxavalent chromium effects on hematological indices in rats. Bull. Environ. Contam. Toxicol., 46:761-768.

Kumar, A. and Kumar, A. (2003). Influence of dietary methionine on hematological indices in chromium poisoned rats. J. Natcon., 15:191-196. 
Kumar, A and Kumar, A. (2006). Vitamins induced inhibition of heavy metal accumulation in the liver of rats. Ind. J. Environ.Sci., 10:103-106.

Kumar. A., Kumar, A. and Dutt, U. (2011). Role of glutathione in modifying liver dysenzymia induced by arsenic in rats. Biochem. Cell. Arch., 11:209-211.

Kumar, A., Kumar. A. and Sharma, P. (2006). Role of glutathione in modifying hepatotoxicity induced by copper in rats. Environ. Conserv. J., 15:95-98.

Kumar, A., Kumar. A. and Sharma, P. (2009). On the reversal of liver dysenzymia by glutathione in chromium poisoned rats. J.Exp.Zool. India, 12:219-222

Kumar, A. and Rana, S.V.S. (1982). Lipid accumulation in chromium poisoned rats. Int. J. Tiss. Reac., 4:291-295.

Kumar, A. and Rana, S.V.S. (1984). Enzymological effects of heaxavalent chromium in rat kidney. Int. J . Tiss. Reac., 6:135139.

Kumar, A., Rana, S.V.S. and Prakash, R. (1985). Dysenzymia induced by hexavalent chromium in rat liver. Int. J. Tiss. Reac., 7:333-338.

Kumar, A., Rana, S.V.S. and Sharma, C.B. (1987). Influence of dietary methionine on copper toxicity in rats. Ad. Bios., 6:1-8.

Lowry, O.H., Rosenbrough, N.J., Farr, A.L. and Randall, R.J. (1951). Protein measurement with the folin phenol reagent. J. Biol. Chem., 193:265-273.

Levy, L.S. and Venitt, S. (1986). Carcinogenicity and mutagenicity of chromium compounds: the association between bronchial metaplasia and neoplasia.. C arcinogenesis, 7: 831-836.

Marks, V.(1959). An improved glucose-oxidation method for determining blood, CSF and urine glucose level. Clin. Chim. Acta., 4:395-399.
Marsh, W.H., Fingerhut, B. and Miller, H.(1965). Automated and manual direct methods for the determination of blood urea. Clin.C hem., 11:624-627.

Mertz, W. (1974).The newer essential trace elements, chromium, tin, vanadium, nickel and silicon. P roc. N utr. Soc., 33:307-313.

Mustafa, M.G., Cowger, M.L. and King, T.E. (1969). Effect of bilirubin on mitochondrial reaction., J. Biol. Chem., 244: 6403-6407.

Oser, B.L. (1976). Hawk's Physiological Chemistry. 14th Edn., Tata Mc Graw Hill, Bombay.

Rajanna, B., Chapatwala, K.D., Vaishnav, D.D. and Desauah, D. (1981). Changes in ATPase activities in tissues of rats fed on cadmium. J.Environ. Biol., 18:726-729.

Rana, S.V.S. and Kumar, A. (1980). On the lipid accumulation in molybadenotic rats. Ind. J. Exp.Biol., 18: 726-728.

Rees, K.R. and Sinha, F.W. (1960). Blood enzymes in liver injury. J. Pathol. B acteriol., 80:297-307.

Schmidt, E. and Schmidt, F.W. (1974). Diagnosis, control of progress therapy disease of liver. In: Bergmeyer H.U. (Ed.), Methods of Enzymatic Analysis (pp. 14-30), Vol. I, Academic Press, New York.

Sharma, P., Kumar, A. and Kumar, A. (2007). Effect of dietary glutathione intake on chromium induced lipid peroxidation in liver of rats. Biochem.C ell. Arch., 7:93-96.

Tandom, S.K. (1982). Organ toxicity of chromium in animals. In : S. Langard (Ed.), Biological and Envirnmental aspects of Chromium. Amsterdam, Elsevier/North-Holland Biomedical Press.pp.209-220

Tandon, S.K., Saxena, D.K., Gour, J.S. and Chandra, S.V. (1978). Comparative toxicity of trivalent and hexavalent chromium.I: Alterations in blood and liver. Environ. Res., 15:90-99. 